\title{
COMPETITIVENESS OF THE CZECH MEAT INDUSTRY ON THE SINGLE MARKET
}

\author{
Ondrej Beňuš ${ }^{1}$
}

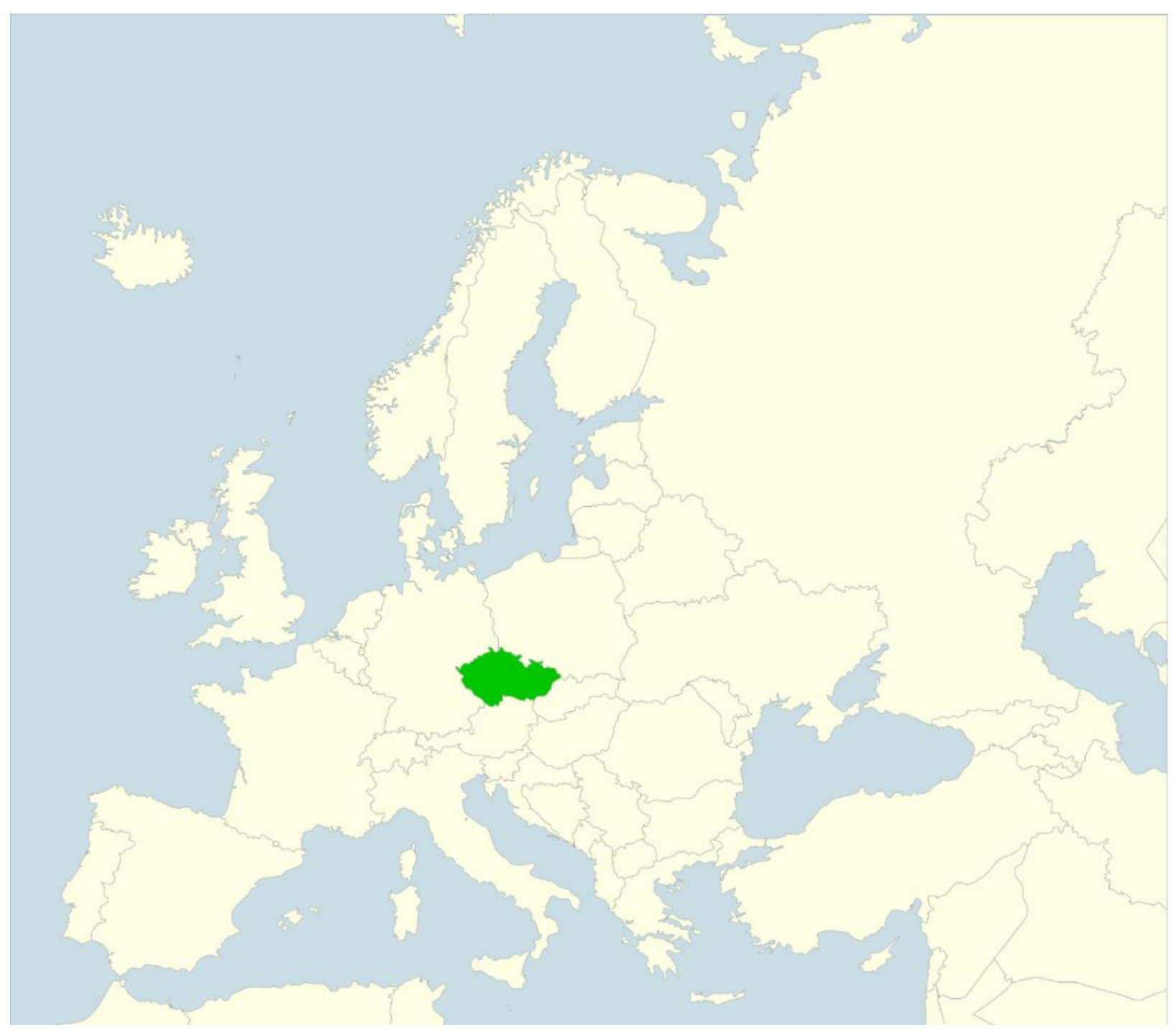

\footnotetext{
${ }^{1}$ Mgr. Ing. Ondrej Beňuš, PhD., e-mail: benus@uniag.sk, Slovak University of Agriculture in Nitra, Slovakia
} 


\begin{abstract}
New Member States have been part of the Single market since joining the European Union in 2004. This step brought various challenges in each of these countries because of appreciable difference in competitiveness compared to old EU Member States. This article puts to the test the competitiveness of the Czech meat industry. This is one of the most important parts of the agri-food production, which is still a very important part of regional economics in less developed regions. Thus, it represents cultural heritage of the countryside. The main aim is to investigate specific branches of the Czech meat industry according to their competitiveness on the Single market. In the article, we make conclusion on different states of the competitiveness of three main branches of the Czech meat industry, which represents $85.6 \%$ of the overall meat export. Conducted research provided information on positive change in the export during the observed period of time, but the comparison of absolute export and import numbers did not refer to a positive development of the Czech meat industry. Furthermore, we observed tendency to locate meat production near local markets and in developed regions.
\end{abstract}

Keywords: meat industry, relative export advantage, relative trade advantage, revealed competitiveness

Abstrakt: Nové členské štáty sú súčast'ou Spoločného trhu EÚ od roku 2004. Táto skutočnost' priniesla rôzne výzvy týmto štátom z dôvodu rozdielov v konkurencieschopnosti v porovnaní so starými členskými štátmi. Ciel’om článku je identifikovat' konkurencieschopnost' mäsopriemyslu $v$ rámci Českej republiky. Tento je jeden z najvýznamnejších prvkov pol'nohospodársko-potravinárskej výroby, ktorá je stále významnou súčast'ou regionálnej ekonomiky v menej rozvinutých regiónoch. Napriek tomu predstavuje kultúrne dedičstvo vidieka. Hlavným cielom je analýza konkurencieschopnosti jednotlivých odvetví mäsopriemyslu Českej republiky na Spoločnom trhu. V rámci článku identifikuje rôznu úroveň konkurencieschopnosti troch najvýznamnejších odvetví mäsopriemyslu tvoriacich $85.6 \%$ celkového exportu. Uskutočnený výskum poskytuje informácie o pozitívnej percentuálnej zmene v exporte počas skúmaného časového úseku. Absolútne hodnoty export a importu však nepoukazovali na pozitívny vývoj. Naviac pozorujeme lokalizáciu mäsopriemyslu v blízkosti vel'kých trhov a rozvinutých regiónov.

Kl'účové slová: mäsopriemysel, relatívna exportná výhoda, relatívna obchodná výhoda, odhalená konkurencieschopnost'

\title{
1. Introduction
}

Meat industry is one of the most dominating branches related to food sector. Mentioned branch of the food sector is the leading power in the words of turnover and employment. This position of the meat industry is then translated into the leading position in export (and import) compared to other branches of the food sector. All these general assumptions corresponding with the situation of the meat industry in the Czech Republic. Development of the production and international trade with this commodity will also shape the overall competitiveness of the food sector in the mentioned country. As research shows, farms focused on raising animals are more profitable than arable farms (Wasilewski and Madra, 2009).

\section{Theoretical background}

Since joining the European Union in 2004, there has been emphasis on the competitiveness of Central European countries in already provided research. Authors investigate the entire process of domestic market adoption to the new competition on the Single market. 
First question is, whether the agri-food trade is intra-trade or inter-trade oriented. Available research suggests, that agri-food trade is primarily intra-trade oriented in developed countries. On the other hand, agri-food production in less developed countries is more export oriented. Central European countries have a specific position, when examining their agri-food export orientation. Compared to the growing trend of inter-trade orientation in developed EU-15 countries, Central European countries are far more intra-trade oriented (Bojnec, 2001).

To this date, agri-food production in Central European countries was put to the test by many authors. In most cases, authors relied on Balassa's (1965) revealed comparative advantage measurement or its modification presented by other authors (Bowen, 1983; Vollrath, 1991; Yu et al., 2009). This methodology is widely spread also in measurement of international competitiveness on the world market (Karsinah et al. 2017, Saubanov et al., 2014).

First measurements of agrarian trade were showing nearly an equal position of Old Member States (EU15) and New Member States (EU12 after 2004) when Old Member States had advantage in products with higher value added (Svatoš et al., 2010). The overall trade of agrofood products in Central European countries started to rise immediately after joining the EU (Bojnec and Fetro, 2008).

Kiss (2011) investigated impacts of the EU accession on the New Member States with focus on agriculture. Based on the researched data from years 2000-2010, she observed an increasing competition on domestic markets and reduction in employment. On the other hand, there had been positive changes in income of employees in agriculture until 2010. According to the author, further research is still required for better understanding of changes brought by the EU accession in the New Member States.

Török and Jambor (2010), after investigating agri-food trade in New Member States between years 1999 and 2010, came to the following conclusions. The increasing agri-food export was apparent. Despite this fact, the dominance of the import to the New Member States over the export was growing constantly. New Member States started to be dependent on the trade inside the Single market. The observed growth of export was mostly oriented on export of agrifood raw materials in the case of the New Member States. On the other hand, the agri-food processed products dominated in import.

Svatoš and Smutka (2014) emphasised the overall change in competitiveness of the agrarian trade of the Central European countries. There were various trends observed among four Central European countries during years 2000 and 2010. Although there was obvious growth of export in the Czech Republic and the Slovak Republic, the measured overall competitiveness of agrarian trade was declining. Hungary and Poland represent competitive markets, according to this study. Strong position in agri-food competitiveness of Poland compared to other Central European countries was identified also by other authors (Poczta and Pawlak, 2011; Firlej et al., 2017).

Growing negative trade balance of overall Czech agricultural trade is caused by a growing difference between export and import in absolute numbers and export orientation on products with minimum level of value added (Bielik et al., 2013; Bojnec and Fertő, 2015). However, latest research has revealed the adoption of agri-food production to the Single market needs in New Member States (Bojnec and Fertő, 2016).

But investigation of overall agri-food competitiveness is not sufficient for precise investigation of the current state and development in this sector. To bring detailed information on the development of the agri-food competitiveness, authors tend to prefer research dedicated to investigation of specific sectors in the last few years (Torok et al., 2016; Bojnec and Fertö, 2016; Simo et al., 2016; Jambor and Gibba, 2017).

Current research suggests that there are also significant differences in meat export competitiveness among European countries (Bojnec and Fertö, 2014).

Competitiveness of the agri-food industry may also play a key role in rural development following current research. Focusing on competitiveness of the agri-food industry highlights also situation of the countryside because it represents one of the most traditional production at these areas. Agriculture and food industry are fundamental industries to fight regional disparities or even 
poverty in rural areas (Anríquez and Stamoulis, 2007; Webb and Block, 2012). There has been prevailing consensus that attracting large companies from highly competitive industries will solve the lack of development potential (and poverty issues) in rural areas (Chang and Huang, 2013). This focus on large international companies and state support has been considered as controversial for its rather heavy orientation on specific industries (Murdoch, 2000). Today, authors prefer (Terluin, 2003; Shucksmith, 2010; Liang-Chih Ch. and Shenglin E. Ch., 2015) local actors and their businesses as the most important source of the further rural development. One of the key problems connected with rural areas represents unemployment. It is often an official cause of migration from rural to urban areas. This problem had occurred also in the Czech Republic. As a result of current research (Putićová and Mezera, 2008), we can identify small enterprises active in the food industry as one of key actors influencing employment in rural areas (evidence from developed EU Member States). Despite massive shift from agriculture and food industry (caused also by productivity growth) to more profitable areas such as services, there is a need to consider the role of these industries in the Czech Republic (Čapkovičová, 2016).

This research dedicated to specific areas of agri-food business can create basis for decisionmaking in the EU, at national and regional level. More precise information on the current state of dedicated areas of agri-food industry also shape development and competitiveness of rural areas. Large firms are predominantly localised in urban regions with well-developed infrastructure. They have easier access to financial institutions, research institutions or authorities at national level. On the other hand, rural areas are characterized by small and middle enterprises with a focus on traditional industries. These entities are challenged by specific problems as "small local markets, isolation from larger markets and remoteness from the business mainstream" (Baker et al., 2007).

Facing these challenges, there are different opinions on drivers influencing competitiveness of these enterprises in the food industry. During last years, there is emphasis on innovation and experience economy of the food industry. Using extensive innovation may be one of sources encouraging local small firms of the food industry for further development. The experience as a source of competitiveness is less dominant but it represents specific potential of small firms in food industry from rural areas (Arthur, 2008).

\section{Methodology}

The main aim of the research was to investigate the current state and development of the Czech meat industry's competitiveness. The main object was the export and import of the meat industry in the Czech Republic inside the territory of the Single Market. For statistical purposes, we used the Combined Nomenclature based on the Council Regulation (EEC) No. 2658/87 of 23 July 1987 on the tariff and statistical nomenclature and on the Common Custom Tariff. In order to deepen our research, we conducted research by investigation of all branches of the meat industry following the classification of the Combined Nomenclature. We will not investigate live animals (classified under Nomenclature "Live animals"). Our investigation is focused on processing industry (classified under Nomenclature "Meat and edible meat offal"). According to the Council Regulation (EEC) No. 2658/87, our research is dedicated to chapter 2.

The following branches of the meat industry were investigated:

- Nomenclature 201 - Meat of bovine animals (fresh or chilled) including:

- carcases

- half-carcases, other cuts with bone

- boneless.

- Nomenclature 202 - Meat of bovine animals (frozen) including:

- carcases

- half-carcases, other cuts with bone

- boneless. 
- Nomenclature 203 - Meat of swine (fresh, chilled or frozen) including:

- fresh or chilled (carcases, half-carcases, hams, shoulders and cuts, other)

- frozen (carcases, half-carcases, hams, shoulders and cuts, other).

- Nomenclature 204 - Meat of sheep or goats (fresh, chilled or frozen)

- carcases and half-carcases of lamb, fresh or chilled

- other meat of sheep, fresh or chilled

- boneless

- carcases and half-carcases of lamb, frozen

- other meat of sheep, frozen

- meat of goats.

- Nomenclature 205 - Meat of horses, asses, mules or hinnies (fresh, chilled or frozen) including:

- fresh or chilled

- frozen.

- Nomenclature 206 - Edible offal of bovine animals, swine, sheep, goats, horses, asses, mules or hinnies (fresh, chilled or frozen) including edible offal:

- of bovine animals (fresh or chilled)

- of bovine animals (frozen)

- of swine (fresh or chilled)

- of swine (frozen)

- others (frozen).

- Nomenclature 207 - Meat and edible offal of the poultry of heading 0105 (fresh, chilled or frozen) including meat and edible offal:

- of flows of the species Gallus domesticus

- of turkeys

- of ducks

- of geese.

- Nomenclature 208 - Other meat and edible meat offal (fresh, chilled or frozen) including meat and edible offal:

- of rabbits and hares

- of primates

- of whales, dolphins and porpoises (mammals of the order Cetacea); of manatees and dugongs (mammals of the order Sirenia); of seals, sea lions and walruses (mammals of the suborder Pinnipedia)

- of reptiles (including snakes and turtles)

- of camels and other camelids (Camelidae)

- others.

- Nomenclature 209 - Pig fat, free of lean meat, and poultry fat, not rendered or otherwise extracted (fresh, chilled, frozen, salted, in brine, dried or smoked) composed of:

- pigs 
- others.

- Nomenclature 210 - Meat and edible meat offal, salted, in brine, dried or smoked; edible flours and meals of meat or meat offal composed of:

- meat of swine

- belies (streaky) and cuts

- others

Following products are not part of our research (excluded from chapter 2 "Meat and edible meat offal"):

- Products of the kinds described in heading 201, 202, 203, 204, 205, 206, 207, 208, 2010, unfit or unsuitable for human consumption.

- Guts, bladders or stomachs of animals and animal blood.

- Animal fat, other than products of heading 209.

Selected branches were investigated for the years 2004-2016. All variables have available date in:

- Trade value.

- One unit representing $100 \mathrm{~kg}$.

We decided to use trade value as a unit (gross value in euro). Our decision was driven by price changes between investigated commodities. Statistical unit is in general every taxable person. However, small and medium operators are exempted from obligation to provide Intrastat declarations.

Observed area covers the territory of the European Union. Our research is focused on movement of selected goods between the Czech Republic and rest of the Member states when exports from the Czech Republic and imports to the Czech Republic are compared for each investigated year.

We are exclusively investigating intra-EU trade. Legislation governing intra-EU trade is represented by Regulation (EC) No 638/2004 of the European Parliament and of the Council of 31 March 2004 on Community statistics relating to the trading of goods between Member States and repealing Council Regulation (EEC) No 3330/91.

The research is mainly based on database provided by EUROSTAT because of the need for international comparison on the Single market. This institution guarantees that all data were constant and based on the same system of data collection, which cannot be said about comparison of national data provided by states.

Our research is primarily oriented on measurement of revealed comparative advantage. However, we decided to measure absolute change in export within investigated branches first. This means that we can clearly compare absolute export change and export competitiveness of the Czech meat industry within the Single market. To offer better visual inside to the observed export changes, we decided to divide investigated branches into 3 groups respecting the following criteria:

- First group consist of branches with export change less than 3x,

- Second group consist of branches with export change 3x or greater but less than 10x,

- Third group consist of branches with export change 10x or greater.

This comparison will offer first insight into the development of the Czech meat export. Observed changes will document real changes inside the Czech meat export.

Our primary aim is to investigate revealed comparative advantage.

Measuring comparative advantage of industries is still actual, although it is a trend from late sixties set by different authors (Liesner, 1958; Balassa, 1965). Balassa (1965) can be considered as 
the pioneer in revealed comparative advantage measurement. His calculation was based on the division of the country's share in the export of a particular commodity and the overall export of the country.

$$
R C A 1_{a}^{i}=\left(\frac{X_{a}^{i}}{X_{a}^{c}}\right) /=\left(\frac{X_{m}^{i}}{X_{m}^{c}}\right)
$$

In the above-mentioned calculation, RCA1 letter $\mathrm{X}$ represents the export and subscript $\mathrm{m}$ refers to combined exports, a refers to a particular product, $i$ to a particular country and $c$ to all observed countries

Although this approach is still popular, we decided to combine export and import data in our research. It can provide broader and more precise information on the comparative advantage. Following Vollrath's (1990) three indicators defined as relative export advantage (RXA), relative trade advantage (RTA) and revealed competitiveness (RCA2), we covered broadly, both export and import changes in observed branches of the Czech meat industry from 2004 to 2016.

$$
\begin{aligned}
& R X A_{a}^{i}=\left(\frac{X_{a}^{i}}{X_{n}^{i}}\right) /\left(\frac{X_{a}^{r}}{X_{n}^{r}}\right) \\
& R M A_{a}^{i}=\left(\frac{M_{a}^{i}}{M_{a}^{c}}\right) /\left(\frac{M_{m}^{i}}{M_{m}^{c}}\right) \\
& R T A_{a}^{i}=R X A_{a}^{i}-R M A_{a}^{i} \\
& R C A 2_{a}^{i}=\operatorname{Ln}\left(R X A_{a}^{i}\right)-\operatorname{Ln}\left(R M A_{a}^{i}\right)
\end{aligned}
$$

In all measured indicators, $X$ represents export and $M$ import. Subscript i refers to selected country, $r$ to all countries (except the country $\mathrm{i}$ ), a to a specific product and $n$ to all products (except the product a).

We focused on import and export data on the Single market. That means all our overall export and import data are restricted on the intra-EU trade.

Based on our measurements, we divided all observed products classified under above-mentioned nomenclatures into three separate groups (based on 2016 calculations):

1. Relative export advantage $>1$, relative trade advantage $>0$, relative competitiveness advantage $>0$

2. Relative export advantage $<1$, relative trade advantage $>0$, relative competitiveness advantage $>0$

3. Relative export advantage $<1$ or $>1$, relative trade advantage $<0$, relative competitiveness advantage $<0$

\section{Results}

Agri-food industry represents traditional industry that maintained its key role in rural areas for a long time. After 1989, there has been a continuous shift toward more modern and profitable sectors. This industrialization of countryside led to erosion of traditional economics (Zegar, 2017). Current situation reflects this shift in the Czech Republic. Available data (Tab. 1) documents relatively small importance of agriculture, forestry and fishing sectors in regional economies of the Czech Republic. Obviously, measured values show that it is impossible to disconnect 
agriculture from the land. That is the reason why this sector will not be transferred into agglomerations by any means in the future.

Tab 1. Czech regional gross value added (GVA) and employment in agriculture, forestry and fishing sector (year 2016, values in \%). Source: Czech Statistical Office, processed by the author

\begin{tabular}{|l|c|c|}
\hline \multicolumn{1}{|c|}{ NUTS 3 level } & GVA & Employment \\
\hline Hlavní město Praha region & 0.47 & 0.41 \\
\hline Středočeský region & 2.96 & 3.23 \\
\hline Jihočeský region & 4.96 & 4.72 \\
\hline Plzeňský region & 3.32 & 3.43 \\
\hline Karlovarský region & 4.04 & 2.25 \\
\hline Ústecký region & 2.43 & 1.80 \\
\hline Liberecký region & 2.07 & 1.60 \\
\hline Královéhradecký region & 3.71 & 3.41 \\
\hline Pardubický region & 3.41 & 3.90 \\
\hline Vysočina region & 4.94 & 6.24 \\
\hline Jihomoravský region & 2.93 & 2.50 \\
\hline Olomoucký region & 3.92 & 3.60 \\
\hline Zlínský region & 2.46 & 2.19 \\
\hline Moravskoslezský region & 1.82 & 1.46 \\
\hline
\end{tabular}

Evidence from last statistical datasets (Figure 1) shows that there is rather significant disproportion in regional meat production. The more interesting thing is that the regional meat production does not support prevailing general theory of its rural character in the case of country observed during our research. Based on the latest data available, there is more orientation on location of the demand than low labour cost (often connected with rural labour force). This fact corresponds more with theories of large-scale production in the food industry and elimination of small and traditional producers from rural areas (Tóth et al.; 2017 Zegar, 2017).

Regions Hlavní město Praha, Středočeský region and Pardubicky region represent $39.23 \%$ of the whole meat production in the Czech Republic. When we take into account the regional GDP, we will encounter the most economically developed regions in the Czech Republic.

On the other side of the measured spectrum, there is the Karlovarský region with only $0.5 \%$ share on overall meat production. This region has the smallest amount of inhabitants living on its territory. Despite this fact, there is evidently a massive gap in meat production between this region and the best regions in this sector. There is 37 times larger amount of meat production in the Pardubický region compared to the Karlovarský region, for example. But the overall population is only twice as large as in the Karlovarský region. Obviously, there are also other drivers of the regional difference than only the number of inhabitants. 

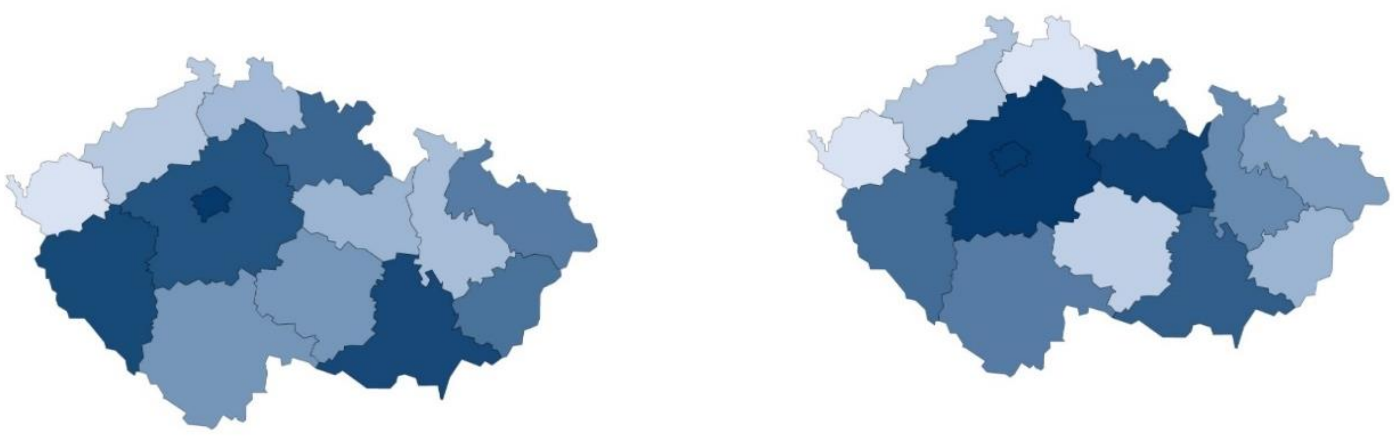

Fig 1. Comparison between the regional GDP (per capita, in current prices) and regional meat production (ton) in the year 2016. Source: Czech Statistical Office, processed by the author

According to the available data, meat industry export of the Czech Republic performed very well compared (Figure 2) to the whole meat export of the EU (on the Single market). The growth of the Czech meat industry export was significantly higher at $175 \%$ compared to the growth of all EU meat exports at the rate of 68\% during observed years (2004-2016). At first glance, it may appear that there is a positive heading of the Czech meat industry. But we cannot omit one fact; the export rate of the EU is represented by strongly dominating saturated markets with already well-developed and competitive domestic meat industry. Thus, it will be more difficult to create additional sources of growth for these highly developed countries which in the end is in correlation with the growth of exports.
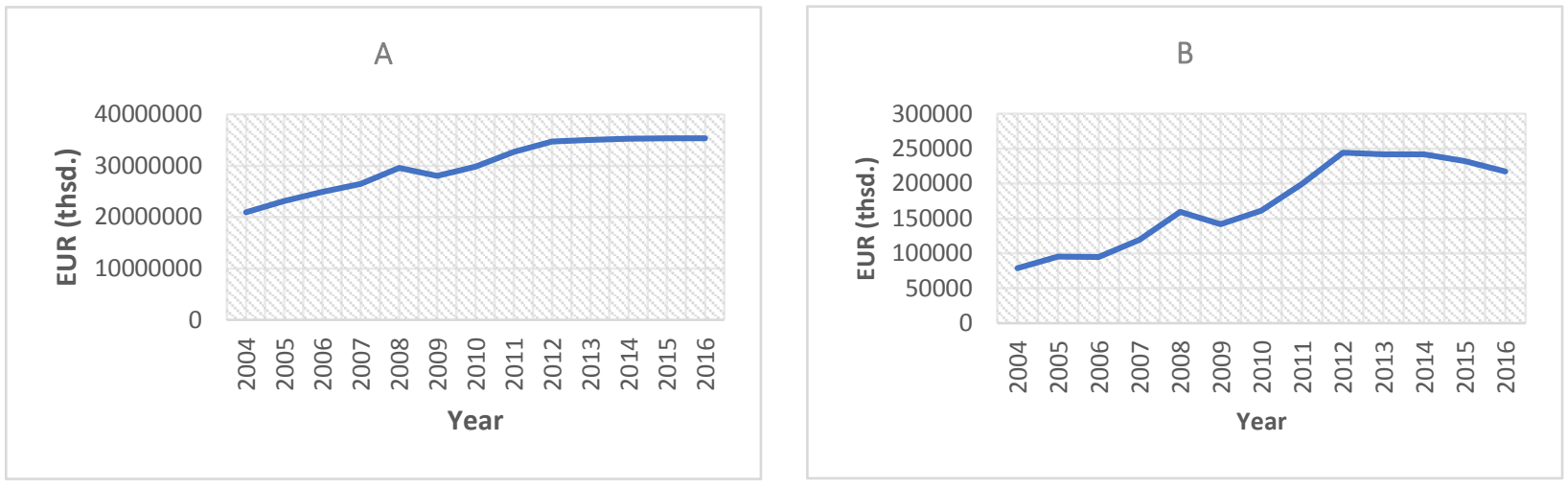

Fig 2. Comparison of meat export (nomenclature 2) in the EU (A) and the Czech Republic (B) (thsd. EUR). Source: Eurostat, 2017, processed by the author
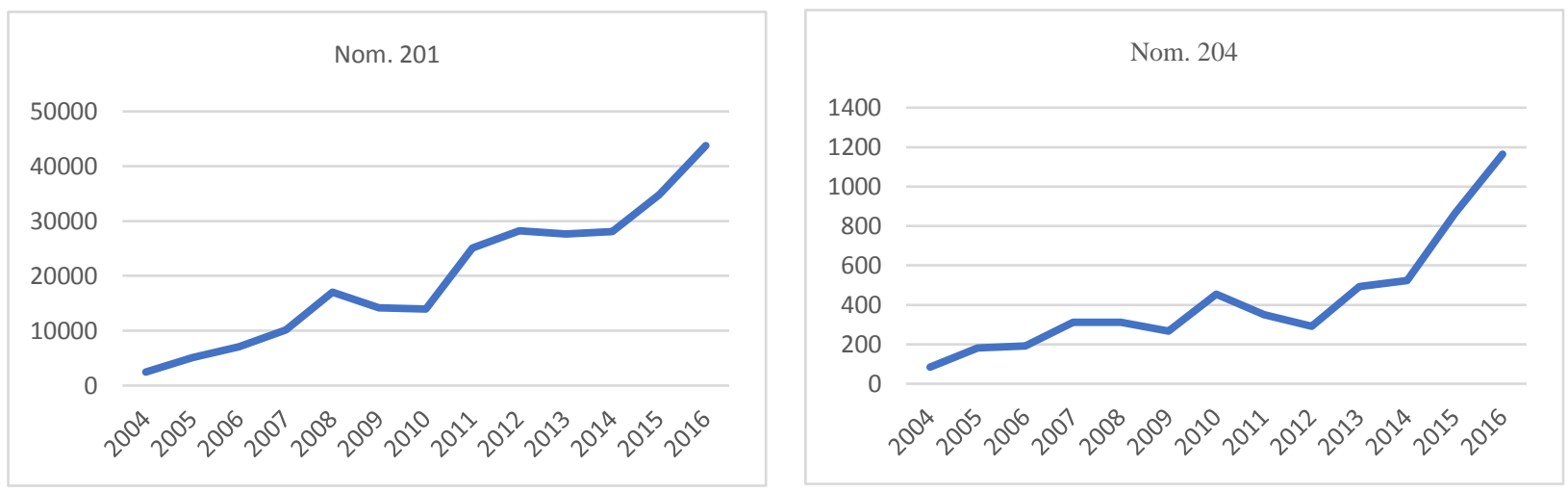

Fig 3. Branches (according to Combined Nomenclature) of the Czech meat industry with export change 10times or more between years 2004-2016 (thsd. EUR, current prices). Source: Eurostat, 2017, processed by author 

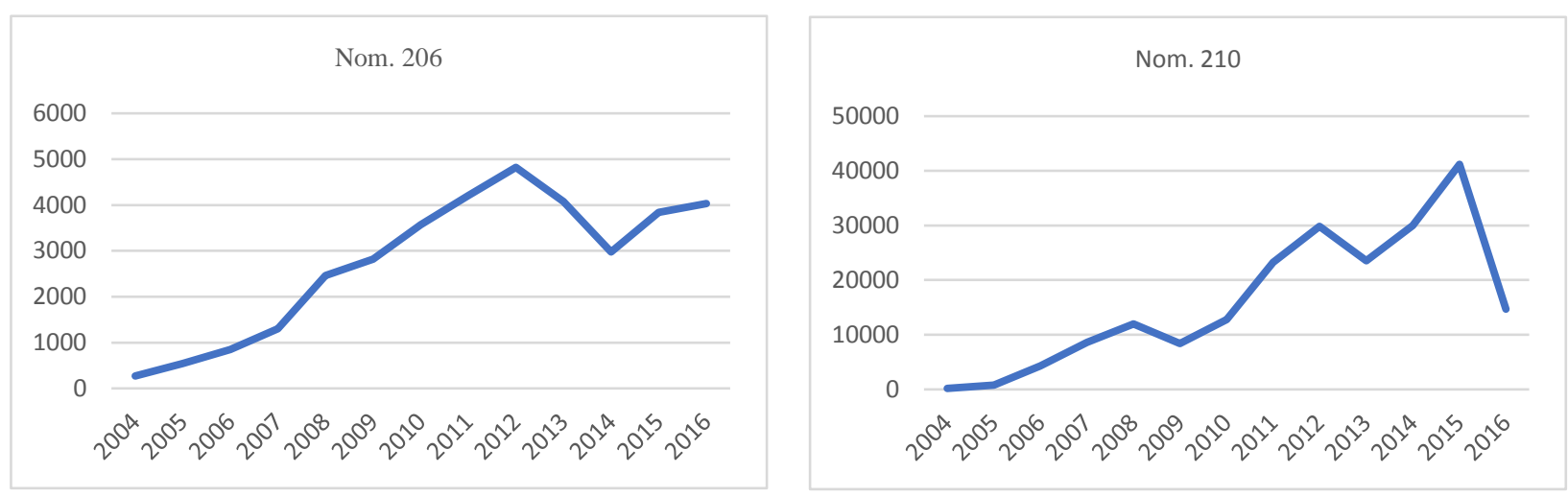

Fig 3. Branches (according to Combined Nomenclature) of the Czech meat industry with export change 10times or more between years 2004-2016 (thsd. EUR, current prices). Source: Eurostat, 2017, processed by author

Some basic conclusions can also be made, by comparing just the year-to-year change in exports. It is obvious that exports from the Czech Republic had experienced significant positive change over observed time. But after a rapid shift in exports, there are first signs of stagnation. We can overlook the year 2009. Both the Czech and EU meat exports declined as a reaction to the financial crisis from 2008. But after this year, EU meat exports began to grow again until the last observed year (2016). On the other hand, Czech meat exports had no additional growth of the meat export after year 2012. This could be the first sign of slowdown in Czech meat export. To find any further information on the structure of Czech meat export, we also investigated the development of all branches of the Czech meat industry.

All observed branches were divided into three separate groups which differ in the percentage of growth between years 2004 and 2016. The first group is represented by branches of theme at industry with growth of export share more than ten times during the observed period of time. The largest shift was measured in export of meat products classified under nomenclature 210 (Meat and edible meat offal, salted, in brine, dried or smoked; edible flours and meals of meat or meat offal). Export of these products rose more than 80 times between years 2004 and 2016 despite the rapid decline in the last observed year (in year 2015, the growth in export was nearly 227 times higher than in year 2004). Products classified under nomenclature 201 (Meat of bovine animals, fresh or chilled) experienced the second largest growth in terms of export value (export grew 17.75 times) and represent the third most influential export branch of the food sector. Items classified under nomenclature 204 (Meat of sheep or goats, fresh, chilled or frozen) and 206 (Edible offal of bovine animals, swine, sheep, goats, horses, asses, mules or hinnies, fresh, chilled or frozen) experienced significant growth in export during the past twelve years (nom 204: 13.8 and nom. 206: 14.9x) but their share on the total meat export is rather limited (at least compared to the above-mentioned products listed under nomenclature 210 and 201).
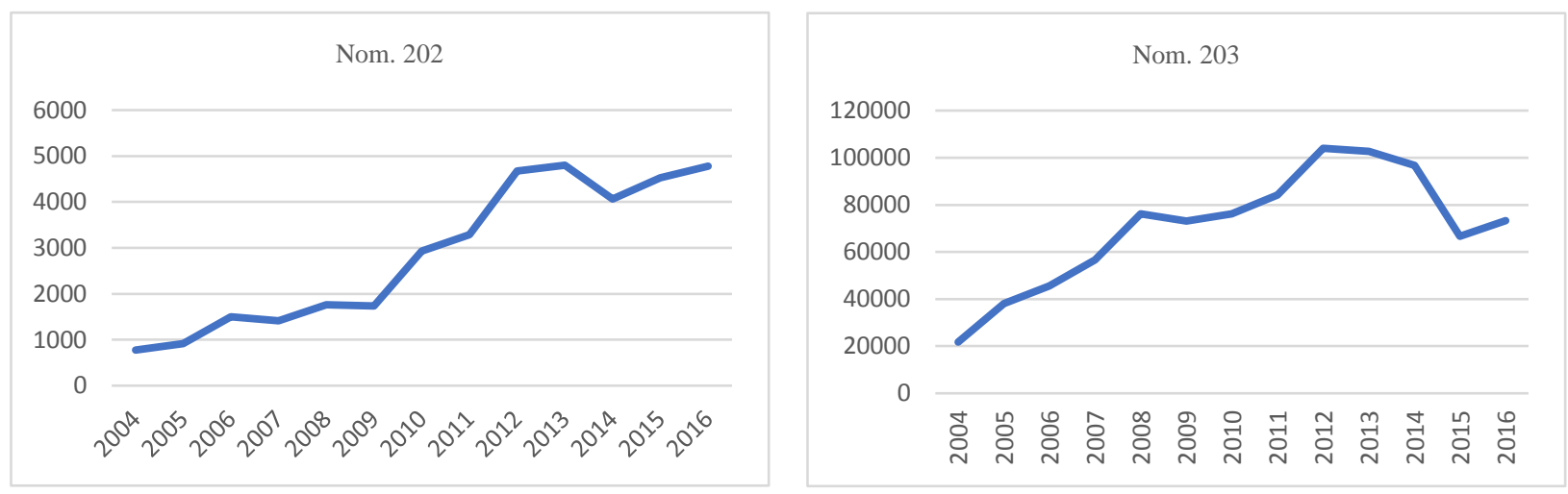

Fig 4. Branches (according to Combined Nomenclature) of the Czech meat industry with export change $3 x$ or greater but less than 10x in years 2004-2016 (thad. EUR, current prices). Source: Eurostat, 2017, processed by author

$452 / 474$ 
The second group represents branches of the meat industry where the growth of the export had risen between three to ten times from 2004 to 2016. Export of products classified under nomenclature 202 (Meat of swine, fresh, chilled or frozen) was 6 times higher in 2016 than in 2004. Products classified under nomenclature 203 (Meat of bovine animals, frozen) rose $3.4 x$ during the observed period. However, these products represent the most important export commodity of the whole Czech meat exports. In this case, the development of export brings first signs of the stagnation in the whole Czech meat exports. Export of these products declined sharply after 2012 and it was at only $70 \%$ in year 2016 (compared to year 2012).

The last selected group is represented by exports with growth lower than $300 \%$ during the observed period. We observed only two items performing worse in 2016 compared to 2004. The first ones are items classified under nomenclature 205 (Meat of horses, asses, mules or hinnies, fresh, chilled or frozen). In this case, in the last observed year, the amount of exports represented only $42.6 \%$ of exports compared to the year 2004 . But the overall impact of products listed under this nomenclature is negligible. The second one is represented by the group of items classified under nomenclature 208 (Other meat and edible meat offal, fresh, chilled or frozen). This time exports were only at $74.5 \%$ compared to the amount of export achieved back in the year 2004. These above-mentioned parts of the Czech meat industry do not represent significant export share and are not influencing the overall competitiveness of the country. Items classified under nomenclature 209 (Pig fat, free of lean meat, and poultry fat, not rendered or otherwise extracted, fresh, chilled, frozen, salted, in brine, dried or smoked) were the best performer of this last group (export rose by 2.6 times) but also in this case we can only refer to limited influence on the overall export of the Czech meat industry.
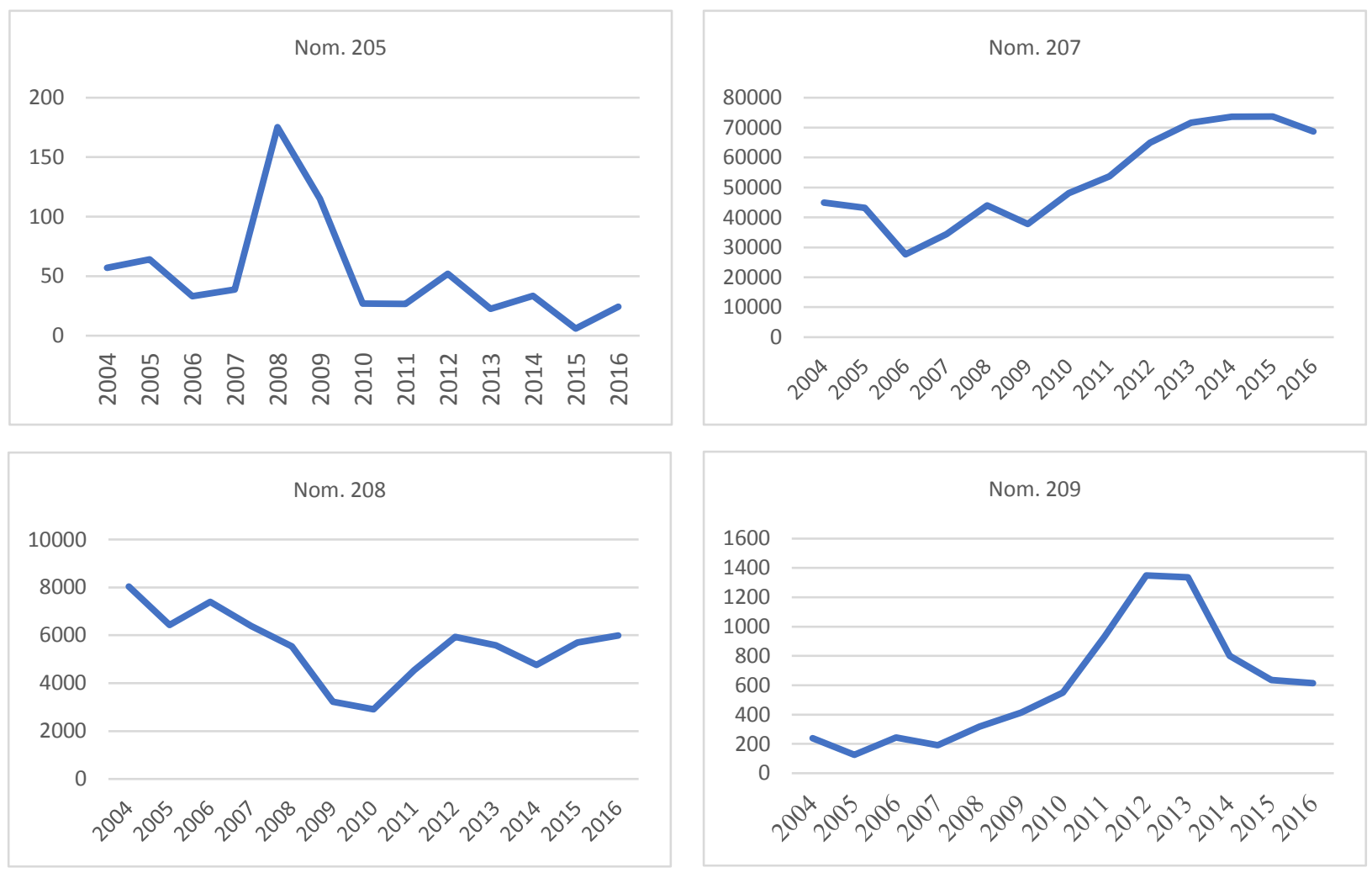

Fig 5. Branches (according to Combined Nomenclature) of the Czech meat industry with export change less than $3 x$ between years 2004-2016 (thsd. EUR, current prices). Source: Eurostat, 2017, processed by author

The most important, in terms of absolute export numbers, is the nomenclature 207 (Meat and edible offal, of the poultry of heading 0105 , fresh, chilled or frozen). Items listed under this nomenclature have the second largest share on the overall Czech meat export. Positive change in export value was maintained until year 2015 when it suddenly dropped by $7 \%$. 
According to this information, we can basically declare that the decline in export of the items listed under nomenclature 203 and 209 was dominantly responsible for lower export competitiveness of the whole Czech meat industry.

This conclusion only reflects the plain amount of the Czech meat export specifically reflecting competitiveness of its different parts according to the chosen nomenclature. Using this plain export oriented data, it cannot be said whether the competitiveness of the Czech meat industry changed or not. For better understanding of the investigated industry, we will consider the overall performance of all EU Member States (related only to the Single market) and compare it with the Czech meat export.

\section{Competitiveness of the Czech meat industry}

The traditional research on competitiveness of the agri-food sector is oriented on both export and import performance (Fertő and Hubbard, 2003; Bojnec and Fertö, 2012; Kiss, 2011) but in the past years, we can witness more and more researches dedicated to the deeper understanding of each branch of food industry (Šimo at al. 2016). We oriented our research on main branches of the Czech meat industry respecting the combined nomenclature.

We divided all observed branches of the Czech meat industry to three separate groups. Their distribution is based on results of three investigated indicators in the last observed year 2016. After distribution of investigated branches of the Czech meat industry, we realized nearly equal share of these groups on total meat export (group no. 1: $34.4 \%$, group no. 2: $31.5 \%$, group no. 3 : $34.1 \%)$.

The first group represents competitive branches of the Czech meat industry fulfilling all three Vollrath's (1990) requirements for competitive advantage (relative export advantage $>1$, relative trade advantage $>0$ and relative competitiveness advantage $>0$ ) in the last observed year (2016). These requirements are by products listed under the following nomenclatures:

- 207 - Meat and edible offal, of the poultry of heading 0105, fresh, chilled or frozen.

- 208 - Other meat and edible meat offal, fresh, chilled or frozen.

Tab 2. $R X A>1, R T A>0, R C A>0$ (according to Combined Nomenclature). Source: own processing

\begin{tabular}{|l|r|r|r|r|r|r|}
\hline & \multicolumn{3}{|c|}{ NOM. 207 } & \multicolumn{3}{c|}{ NOM. 208 } \\
\hline & RXA & RTA & RCA & RXA & RTA & RCA \\
\hline $\mathbf{2 0 0 4}$ & 6.10 & 4.59 & 1.39 & 7.53 & 7.28 & 3.43 \\
\hline $\mathbf{2 0 0 5}$ & 3.72 & 2.25 & 0.93 & 5.51 & 5.01 & 2.40 \\
\hline $\mathbf{2 0 0 6}$ & 2.11 & 0.59 & 0.33 & 6.42 & 5.84 & 2.40 \\
\hline $\mathbf{2 0 0 7}$ & 1.75 & 0.70 & 0.51 & 4.11 & 3.78 & 2.52 \\
\hline $\mathbf{2 0 0 8}$ & 1.82 & 0.60 & 0.40 & 2.80 & 2.26 & 1.66 \\
\hline $\mathbf{2 0 0 9}$ & 1.78 & 0.60 & 0.41 & 2.01 & 1.74 & 1.99 \\
\hline $\mathbf{2 0 1 0}$ & 1.92 & 0.76 & 0.50 & 1.49 & 1.16 & 1.52 \\
\hline $\mathbf{2 0 1 1}$ & 1.58 & 0.34 & 0.24 & 2.07 & 1.82 & 2.15 \\
\hline $\mathbf{2 0 1 2}$ & 1.56 & 0.27 & 0.19 & 2.43 & 1.73 & 1.24 \\
\hline $\mathbf{2 0 1 3}$ & 1.82 & 0.58 & 0.38 & 2.23 & 1.72 & 1.48 \\
\hline $\mathbf{2 0 1 4}$ & 1.75 & 0.49 & 0.33 & 1.75 & 1.29 & 1.34 \\
\hline $\mathbf{2 0 1 5}$ & 1.74 & 0.35 & 0.22 & 2.00 & 1.54 & 1.47 \\
\hline $\mathbf{2 0 1 6}$ & 1.72 & 0.45 & 0.30 & 2.48 & 1.98 & 1.61 \\
\hline
\end{tabular}

Nomenclature 208 achieved the best results in all our measurements of investigated branches of the Czech meat industry. Products listed under this nomenclature had experienced the best overall export advantage until the last observed year 2016. Relative trade advantage and 
the revealed competitiveness advantage were positive, too. Based on previous findings we already know, that the whole share on the Czech meat export is relatively limited in this case. After taking into account the real value of export, we do not consider products listed under this nomenclature as the main power of the overall meat export. The second mentioned nomenclature has significantly more importance. Products listed under nomenclature 207 fulfilled all requirements for revealed export advantage, relative trade advantage and revealed competitiveness advantage. But even more important is the relatively dominant share of these products on overall exports (second position) of the investigated country. It is positive that products listed under nomenclature 207 retained their competitiveness, on one hand. But on the other hand, we have to highlight the relative loss of the influence of Czech export during the observed time. Both above-mentioned experienced loss in all three measured indicators. This brings us to the conclusion that also these above-mentioned best scoring products classified under nomenclature 207 and 208 witnessed loss of their export advantages on the Single market during the years 2004 and 2016.

The second group represents products classified under nomenclatures which experienced positive relative trade advantage (RTA) and revealed competitiveness (RCA) in the last observed year 2016. Compared to the first group, none of these products achieved relative export advantage $(R X A>1)$. This second group is represented by the highest number of investigated branches of the Czech meat industry but the total share on overall meat export is the smallest one. In terms of the share on total meat export, the most important products are represented by nomenclature 201. Products classified under nomenclature 210 (Meat and edible meat offal, salted, in brine, dried or smoked; edible flours and meals of meat or meat offal) represented the fourth most important export article of the Czech meat industry and scored the highest in terms of relative export advantage (RXA: 0.92), nearly fulfilling the requirement for overall competitiveness set for the first group of investigated branches of the meat industry.

Tab 3. RTA $>0$ and $R C A>0$ (according to Combined Nomenclature). Source: own processing

\begin{tabular}{|l|c|c|c|c|c|c|c|c|c|c|c|c|c|c|c|}
\hline & \multicolumn{3}{|c|}{ NOM. 201 } & \multicolumn{3}{|c|}{ NOM. 202 } & \multicolumn{3}{c|}{ NOM. 204 } & \multicolumn{3}{c|}{ NOM. 206 } & \multicolumn{3}{c|}{ NOM. 210 } \\
\hline & RXA & RTA & RCA & RXA & RTA & RCA & RXA & RTA & RCA & RXA & RTA & RCA & RXA & RTA & RCA \\
\hline $\mathbf{2 0 0 4}$ & 0.10 & -0.11 & -0.74 & 0.31 & -0.59 & -1.06 & 0.03 & -0.11 & -1.62 & 0.12 & -2.16 & -2.95 & 0.03 & -0.07 & -1.30 \\
\hline $\mathbf{2 0 0 5}$ & 0.17 & -0.13 & -0.56 & 0.31 & -0.55 & -1.03 & 0.05 & -0.08 & -1.03 & 0.19 & -1.21 & -2.01 & 0.11 & -0.01 & -0.12 \\
\hline $\mathbf{2 0 0 6}$ & 0.22 & -0.10 & -0.38 & 0.51 & -0.01 & -0.02 & 0.05 & -0.06 & -0.83 & 0.33 & -0.82 & -1.25 & 0.58 & 0.15 & 0.29 \\
\hline $\mathbf{2 0 0 7}$ & 0.26 & -0.10 & -0.32 & 0.38 & -0.13 & -0.30 & 0.08 & -0.05 & -0.50 & 0.45 & -0.46 & -0.70 & 0.87 & -0.15 & -0.16 \\
\hline $\mathbf{2 0 0 8}$ & 0.34 & 0.05 & 0.17 & 0.33 & 0.01 & 0.04 & 0.06 & -0.03 & -0.39 & 0.54 & -0.37 & -0.53 & 0.95 & 0.17 & 0.20 \\
\hline $\mathbf{2 0 0 9}$ & 0.30 & -0.01 & -0.03 & 0.39 & 0.09 & 0.27 & 0.05 & -0.02 & -0.35 & 0.67 & -0.23 & -0.30 & 0.76 & 0.25 & 0.39 \\
\hline $\mathbf{2 0 1 0}$ & 0.28 & -0.06 & -0.19 & 0.58 & 0.22 & 0.47 & 0.08 & -0.01 & -0.08 & 0.73 & -0.08 & -0.10 & 1.06 & 0.43 & 0.53 \\
\hline $\mathbf{2 0 1 1}$ & 0.41 & 0.10 & 0.27 & 0.54 & 0.16 & 0.35 & 0.05 & -0.05 & -0.69 & 0.68 & -0.15 & -0.20 & 1.68 & 0.95 & 0.84 \\
\hline $\mathbf{2 0 1 2}$ & 0.38 & 0.11 & 0.36 & 0.59 & 0.28 & 0.65 & 0.04 & -0.03 & -0.62 & 0.58 & -0.23 & -0.34 & 1.83 & 1.32 & 1.29 \\
\hline $\mathbf{2 0 1 3}$ & 0.39 & 0.09 & 0.25 & 0.65 & 0.31 & 0.65 & 0.06 & -0.03 & -0.39 & 0.53 & -0.19 & -0.31 & 1.37 & 0.84 & 0.95 \\
\hline $\mathbf{2 0 1 4}$ & 0.40 & 0.05 & 0.13 & 0.57 & 0.23 & 0.53 & 0.06 & -0.02 & -0.32 & 0.39 & -0.20 & -0.40 & 1.71 & 1.21 & 1.22 \\
\hline $\mathbf{2 0 1 5}$ & 0.50 & 0.15 & 0.35 & 0.61 & 0.24 & 0.49 & 0.10 & 0.00 & 0.00 & 0.58 & 0.04 & 0.07 & 2.59 & 2.05 & 1.57 \\
\hline $\mathbf{2 0 1 6}$ & 0.72 & 0.26 & 0.44 & 0.69 & 0.34 & 0.66 & 0.14 & 0.05 & 0.38 & 0.68 & 0.09 & 0.15 & 0.92 & 0.48 & 0.74 \\
\hline
\end{tabular}

The remaining products classified under nomenclature 202 (Meat of bovine animals, frozen), 204 (Meat of sheep or goats, fresh, chilled or frozen) and 206 (Edible offal of bovine animals, swine, sheep, goats, horses, asses, mules or hinnies, fresh, chilled or frozen) experienced positive shift in all measured indicators (relative export advantage, relative trade advantage and revealed competitiveness) during the observed years. Rising importance of these products is documented by the growth of their share on the total Czech meat export (export grew 3.2x compared to 2.75 of total export of the meat industry). On the other hand, these products had only $4.6 \%$ share on the overall meat export in 2016 and their influence on competitiveness of investigated industry is still only limited. All products listed in this second group had experienced 
positive changes in all three measured indicators until the last observed year 2016. When positive changes in value of export are added, we can conclude a good adoption on the competitive Single market in this case. Despite some concerns connected with the stagnation of the overall performance of the Czech meat export after 2012, these products listed under above-mentioned nomenclatures experienced significant loss of competitiveness to the end of observed time.

Tab 4. $R X A<1$ and $R T A<0$ (according to Combined Nomenclature). Source: own processing

\begin{tabular}{l|ccccccccc}
\multicolumn{3}{c}{} & \multicolumn{3}{c}{ NOM. 203 } & \multicolumn{3}{c}{ NOM. 205 } & \multicolumn{3}{c}{ NOM. 209 } \\
\hline & RXA & RTA & RCA & RXA & RTA & RCA & RXA & RTA & RCA \\
$\mathbf{2 0 0 4}$ & 0.75 & -1.48 & -1.09 & 0.09 & -0.99 & -2.46 & 0.34 & -5.22 & -2.80 \\
$\mathbf{2 0 0 5}$ & 1.29 & -1.07 & -0.60 & 0.09 & -0.74 & -2.22 & 0.17 & -2.70 & -2.82 \\
$\mathbf{2 0 0 6}$ & 1.80 & -0.63 & -0.30 & 0.05 & -0.38 & -2.17 & 0.37 & -2.08 & -1.90 \\
$\mathbf{2 0 0 7}$ & 1.84 & -0.68 & -0.32 & 0.04 & -0.18 & -1.62 & 0.26 & -1.99 & -2.16 \\
$\mathbf{2 0 0 8}$ & 1.79 & -0.88 & -0.40 & 0.16 & -0.19 & -0.79 & 0.20 & -2.72 & -2.70 \\
$\mathbf{2 0 0 9}$ & 2.03 & -0.95 & -0.38 & 0.12 & -0.18 & -0.91 & 0.34 & -2.70 & -2.19 \\
$\mathbf{2 0 1 0}$ & 1.73 & -1.10 & -0.49 & 0.03 & -0.17 & -1.97 & 0.48 & -2.23 & -1.73 \\
$\mathbf{2 0 1 1}$ & 1.49 & -1.18 & -0.59 & 0.02 & -0.12 & -1.88 & 0.53 & -2.46 & -1.73 \\
$\mathbf{2 0 1 2}$ & 1.49 & -1.35 & -0.64 & 0.04 & -0.15 & -1.68 & 0.62 & -1.93 & -1.42 \\
$\mathbf{2 0 1 3}$ & 1.44 & -1.37 & -0.67 & 0.02 & -0.08 & -1.70 & 0.70 & -1.70 & -1.23 \\
$\mathbf{2 0 1 4}$ & 1.39 & -1.44 & -0.71 & 0.03 & -0.09 & -1.53 & 0.47 & -1.60 & -1.48 \\
$\mathbf{2 0 1 5}$ & 0.92 & -1.87 & -1.11 & 0.00 & -0.11 & -3.14 & 0.50 & -1.59 & -1.44 \\
$\mathbf{2 0 1 6}$ & 1.15 & -1.57 & -0.86 & 0.02 & -0.05 & -1.14 & 0.50 & -1.38 & -1.33
\end{tabular}

The last group represents the products listed under nomenclature, which did not meet any of the requirements set up for competitiveness with one exception. Our calculations revealed that nomenclature 203 (Meat of swine, fresh, chilled or frozen) experienced relative export advantage in year 2016. Products listed under this nomenclature had the highest share on the total Czech meat export (33.8\%) in year 2016. In terms of export, these products experienced the best relative export advantage in year 2009. This means that the loss in export advantage started even before the stagnation of overall meat export in this case. The only year these products lost their relative export advantage $(R X A<1)$ was the year 2015 . If we add the change in export to our calculation, we will come to a different result. The relative trade advantage was the worst compared with all other investigated nomenclatures in this group (reference year 2016). In all other cases, we measured positive change in relative trade advantage in year 2016 (compared to 2004). This reflects the growing imports of products classified under nomenclature 203 in the Czech Republic. Other two nomenclatures listed in this group have only limited importance because of their small share on the overall Czech meat export (nomenclature 205: 0.0001\% and nomenclature 209: $0.0028 \%)$.

\section{Discussion and Implications}

Czech Republic experienced significant changes in the competitiveness of the meat industry after joining the EU. The country benefited from the Single market and export grew substantially (2008: 33.7\%, 2007: $26 \%$ and 2012: 22.3\%) during years 2004-2016. But import experienced even more evident growth (2004: 160.4\%, 2005: 64.8\% and 2008: 24.1\%). The Czech meat export had grown by $3.2 x$ and import by $4.91 x$ from the time of joining the EU until the last observed year 2016. Thus, during the whole investigated period of time, the predominance of meat import over meat export in the Czech Republic was apparent.

The aggregated values of export and import do not provide satisfactory information on the competitiveness of the Czech meat industry. We executed a detailed investigation by dividing products of the Czech meat industry based on the combined nomenclature. We measured both export and import of each nomenclature using Vollrath's (1991) three indicators: relative export 
advantage, relative trade advantage and revealed competitiveness. There has been disproportion in competitiveness of investigated nomenclatures during observed years. The nomenclatures with dominant share on the overall Czech meat export, generating $85.6 \%$ of overall export (2016), performed differently.

Products listed under nomenclature 207 (Meat and edible offal, of the poultry of heading 0105 , fresh, chilled or frozen) had the second largest share on the overall Czech meat export in 2016. These products achieved positive results in all three investigated indicators (RXA: 1.72, RTA: $0.45, \mathrm{RCA}: 0.3$ ) and were classified in the best performing group. On the other hand, all measured indicators signalised downturn in export advantage and overall competitiveness of these products on the Single market. This information gained from our calculations is backed by the growth of exports by $1.53 x$ (only at $47.8 \%$ compared to the overall growth of the Czech meat industry) compared to the growth of imports by 4.8x. The difference between export and import was 179,124 EUR in 2016 compared to 7,233 EUR in 2004. Based on this trend and observed stagnation of the Czech meat export after the year 2012, we predict loss in competitiveness of products listed under nomenclature 207 in near future.

Second group of products was characterized by positive relative trade advantage and revealed competitiveness, but it lacked the relative export advantage. The most influential were products classified under nomenclature 201 (Meat of bovine animals, fresh or chilled) in the second group. These products achieved the third largest share on the overall Czech meat export in 2016. According to our calculation, these products show signs of revealed competitiveness in the last observed year. The positive thing in this case is the founding, that all three measured indicators had shown growth during investigated years. In the last measured year, products classified under nomenclature 201 achieved the best results considering the changes between years 2004 and 2016. This was supported by development of measured changes in export and import. Export grew by 17.8x (average of the industry was 3.2x) and import grew by 10.6x (average of the industry was $4.91 \mathrm{x})$.

The last group created, resulting from our research was characterized by products lacking the positive result in relative trade advantage and revealed competitiveness. Products listed under nomenclature 203 (Meat of swine, fresh, chilled or frozen) had the largest share on the overall Czech meat export in 2016. Considering the amount of export in the European Union, we measured relative export advantage of this products in 2016. But this was not enough to gain the revealed competitiveness and we measured the highest negative trade balance of 453,123 EUR in 2016 (compared to 83,861 EUR in 2004). The growth in export and import was in line with the average of the Czech meat industry.

It is important to mention that competitiveness of the food industry is related to profitability of farms raising animals. These farms struggle to keep their operation running. There are multiple tools regulating competitiveness of these farms, but their targeting is not always optimal (Doucha et al., 2012). This is partially a problem connected with large farms focusing only on crop production because of the current CAP structure. Also, latest research conducted in the Slovak Republic has shown no growth in animal production because of its labour cost intensity. This structure of funding is criticized in current literature (Tóth, 2017). Flat rate support does not correlate efforts put into lowering of regional disparities. These instruments should have more variable measures with focus on farm size and structure of the production. More support should be intended for small farms with seat directly on the countryside. This action would help to maintain employment and food production securing rural development (Wieliczko, 2017), national food security (Alexandri et al., 2015) and cultural heritage (Cizler, 2013). This effort should not only be oriented on market outputs and profitability. There is also social responsibility to secure adequate proportion of industries. The role of agriculture and food industry in rural areas should be covered, too. Effective and reasonable use of land is one of areas that is covered by these mentioned sectors of national economy. Creating shorter supplier-customer chains based on local food production would have positive effect on development of rural areas and quality of offered products. And in the end, creating effective local agriculture and food production will maintain cultural heritage of rural areas. 


\section{Conclusions}

According to the above-mentioned findings, we conclude the overall export potential of the Czech meat industry had been growing during observed period of time. But on the other hand, signs of potential stagnation occurred at the end of the investigated period of time. It is obvious that there was massive pressure on domestic market and its competitiveness after the Czech Republic joined the EU in 2004. Previous research also supports the idea that improving the export potential can lead to improvement of the whole food processing industry (Bojnec and Fertö, 2014)

Our research revealed that, there are three key branches of the Czech meat export representing the driving force of competitiveness. Each of these branches behaved differently during the observed period of time. Products listed under nomenclature 203 (Meat of swine, fresh, chilled or frozen) represent the most important branch of the Czech meat industry. Unfortunately, these products are not competitive on the Single market.

The next research should be oriented on further investigation of forces determining competitiveness of the Czech meat industry and proper adoption of the Common agricultural policy.

\section{Academic references}

[1] Alexandri, C., Luca, L. \& Kevorchian, C. (2015). Subsistence Economy and Food Security The Case of Rural Households from Romania. Procedia Economics and Finance, 22(1): 672-680. DOI: 10.1016/S2212-5671(15)00282-8.

[2] Anríquez, G. \& Stamoulis, K. (2007). Rural development and poverty reduction: is agriculture still the key? Journal of Agricultural and Development Economics, 4(1): 5-46.

[3] Balassa, B. (1965). Trade Liberalization and Revealed Comparative Advantage. The Manchester School, 33(2): 99-123. DOI: 10.1111/j.1467-9957.1965.tb00050.x.

[4] Baker, D., Jensen, T. V., Das, D. \& Dalgaard, T. (2007). Survey of Danish food industry firms'views on policies that impact food industry [Working Paper]. University of Københaven.

[5] Bielik, P., Smutka, L., Svatoš, M. \& Hupková, D. (2013). Czech and Slovak agricultural foreign trade - two decades after the dissolution. Agricultural Economics, 59(10): 441-453.

[6] Bojnec, Š. (2001). Trade and revealed comparative advantage measures: regional and Central and East European agricultural trade. Eastern European Economics, 39(2), 72-98. DOI: 10.1080/00128775.2001.11040990.

[7] Bojnec, Š. \& Fertő, I. (2008). European enlargement and agro-food trade. Canadian Journal of Agricultural Economics, 56(4), 563-579. DOI: 10.1111/j.1744-7976.2008.00148.x.

[8] Bojnec, Š. \& Fertő, I. (2012). Complementarities of trade advantage and trade competitiveness measures. Applied Economics, 44(4): 399-408. DOI: $10.1080 / 00036846.2010 .508725$.

[9] Bojnec, Š. \& Fertő, I. (2014). Meat export competitiveness of European Union countries on global markets. Agricultural and Food Science, 23(3), 194-206. DOI: 10.3168/jds.20137711.

[10] Bojnec, Š. \& Fertő, I. (2014). Export competitiveness of dairy products on global markets: The case of the European union countries. Journal of Dairy Science, 97(3), 6151-6163. DOI: $10.3168 /$ jds.2013-7711.

[11] Bojnec, Š. \& Fertő, I. (2015). Agri-food Export Competitiveness in European Union Countries. Journal of Common Market Studies, 53(3): 476-492. DOI: 10.1111/jcms.12215.

[12] Bojnec, S. \& Fertő, I. (2016). Export competitiveness of the European Union in fruit and vegetable products in the global markets. Agricultural Economics, 62(7): 299-310. DOI: 10.17221/156/2015-AGRICECON. 
[13] Bojnec, Š. \& Fertő, I. (2016). Patterns and drivers of the agri-food intra-industry trade of European Union Countries. International Food and Agribusiness Management Review, 19(2): 53-74.

[14] Chang, S. E. \& Huang, P. (2013). Any way to our Huilan home: Building the Suhua freeway or taking the Bali detour? Journal of ASIAN Behavioural Studies, 3(9): 15-28. DOI: $10.21834 / j a b s . v 3 i 6.232$.

[15] Cizler, J. (2013). Opportunities for the Sustainable Development of Rural Areas in Serbia. Problemy Ekorozwoju - Problems of Sustainable Development, 8(2): 85-91.

[16] Čapkovičová, A. (2016). Transformation of the employment base in Czech rural regions. Regional Studies, Regional Science, 3(1): 229-238. DOI: 10.1080/21681376.2016.1165626.

[17] Doucha, T., Štolbová, M. \& Lekešová, M. (2012). Assessment of support for farms in the Czech less favoured areas with special regards to cattle breeding. European Countryside, 4(3), 179-191. DOI: 10.2478/v10091-012-0022-7.

[18] Fertő, I. \& Hubbard, L. J. (2003). Revealed Comparative Advantage and Competitiveness in Hungarian Agri-Food Sectors. The World Economy, 26(2): 247-259. DOI:10.1111/14679701.00520.

[19] Firlej, K., Kowalska, A. \& Piwowar, A. (2017). Competitiveness and innovation of the Polish food industry. Agricultural Economics, 63(11), 502-509. DOI: 10.17221/111/2016AGRICECON.

[20] Harry, P. B. (1983). On Theoretical Interpretation of Indices of Trade Intensity and Revealed Comparative Advantage. Weltwirtschaftliches Archiv, 119(3), 464-472. DOI: $10.1007 / B F 02706520$.

[21] Jambor, A. \& Gibba, A. (2017). Competitiveness in global agri-food trade: the case of peanuts. Bulgarian Journal of Agriculture Science, 23 (2): 177-182.

[22] Karsinah, Oktavilia, S., Rahman, Y. A., Setiawan, A. B., Firmansyah, Widodo W. (2017). Analysis for the export competitiveness of food and agricultural commodities in central Java Province, Indonesia. Advanced Science Letters, 23(8): 7150-7152. DOI: 10.1166/asl.2017.9313.

[23] Kiss, J. (2011). Some impacts of the EU accession on the new member states' agriculture. Eastern Journal of European Studies, 2(2): 49-60. DOI: 10.1080/14631377.2013.813139.

[24] Liang-Chih, Ch. \& Shenglin, E. Ch. (2015). Building and Recovering Rural Economic Landscapes: The case of liquor and tea industries in Taiwan. Procedia - Social and Behavioral Sciences, 7 (38), 408-416. DOI: 10.1016/j.sbspro.2015.08.245.

[25] Liesner, H. H. (1958). The European Common Market and British Industry. The Economic Journal, 68(270): 302-316. DOI: 10.2307/2227597.

[26] Murdoch, J. (2000). Networks: A new paradigm of rural development? Journal of Rural Studies, 16 (4): 407-419. DOI: 10.1016/S0743-0167(00)00022-X.

[27] Poczta, W. \& Pawlak, K. (2011). Potential competitiveness and competitive position of the Polish agri-food sector on the single European market. Berichte uber Landwirtschaft, 89(1): 134-169.

[28] Putićová, M. \& Mezera, J. (2008). Food industry in the Czech Republic - with regard to labour force development. Agricultural Economics, 54(6): 285-292.

[29] Saubanov, K. R., Bagautdinova, N. G. \& Maklakova, N. V. (2014). The state of competitiveness of Russia on the world food market. Mediterranean Journal of Social Sciences, 5 (28): 36-39. DOI: 10.5901/mjss.2014.v5n28p36.

[30] Shucksmith, M. (2010). Disintegrated rural development? Neo-endogenous rural development, planning and place-shaping in diffused power contexts. Sociologia Ruralis, 50 (1): 1-14. DOI: 10.1111/j.1467-9523.2009.00497.x. 
[31] Simo, D., Mura, L. \& Buleca, J. (2016). Assessment of milk production competitiveness of the Slovak Republic within the EU-27 countries. Agricultural Economics, 62(10): 482-492. DOI: $10.17221 / 270 / 2015-A G R I C E C O N$.

[32] Svatoš, M. \& Smutka, L. (2014). Visegrad countries - agrarian foreign trade development in relation to their total merchandise trade performance. Scientific Journal Warsaw University of Life Sciences, 14(4): 158-172.

[33] Svatoš, M., Smutka, L. \& Miffek, O. (2016). Competitiveness of agrarian trade of EU-15 countries in comparison with new EU member states. Agricultural Economics, 56(12): 569582.

[34] Toth, M., Strapekova, Z. \& Rabek, T. (2017). Why Large Farms Dominate and Rural Areas Struggle in Slovakia. In Wiger, M. \& Kowalski, A., eds., Strategies for the agri-food sector and rural areas - dilemmas of development (pp. 196-209). Warszawa: Instytut rolnicztwa I gospodarki zywnosciowej. DOI: 10.2139/ssrn.3104607.

[35] Terluin, I. J. (2003). Differences in economic development in rural regions of advanced countries: An overview and critical analysis of theories, Journal of Rural Studies, 19 (3): 327344. DOI: 10.1016/S0743-0167(02)00071-2.

[36] Török, A. \& Jambor, A. (2013). Agri-food trade of the New Member States since EU accession. Agricultural Economics, 59(3), 101-112.

[37] Török, A. \& Jambor, A. (2016). Determinants of the revealed comparative advantages: The case of the European ham trade. Agricultural Economics, 62: 471-481. DOI: $10.17221 / 177 / 2015-A G R I C E C O N$.

[38] Vollrath, T. L. (1991). A theoretical evaluation of alternative trade intensity measures of revealed comparative advantage. Weltwirtschaftliches Archiv, 130: 265-279.

[39] Webb, P. \& Block, S. (2012). Support for agriculture during economic transformation: Impacts on poverty and undernutrition. Proceedings of the National Academy of Sciences. Proceedings of the National Academy of Sciences of the United States of America. 109(31): 12309-12314. DOI: 10.1073/pnas.0913334108.

[40] Wasilewski, M. \& Madra, M. (2009). Regional Differentiation of the Use of Production Factors in the Polish Agriculture. European Countryside, 1(1), 22-23. DOI: 10.2478/v10091-0090003-7.

[41] Wieliczko, B. (2017). Backasting as an Approach to Creating Long-Term Development Strategies for the Agri Food Sector. In Wiger, M. \& Kowalski, A., eds., Strategies for the agrifood sector and rural areas - dilemmas of development (pp. 17-26). Warszawa: Instytut rolnicztwa i gospodarki zywnosciowej.

[42] Yu, R., Cai, J. \& Leung, P. (2009). The Normalized Revealed Comparative Advantage Index. The Annals of Regional Science, 43(1), 267-282. DOI: 10.1007/s00168-008-0213-3.

[43] Zegar, J. S. (2017). Strategic Dilemmas of the Rural and Farming Policy in Poland. In Wiger, M. \& Kowalski, A., eds., Strategies for the agri-food sector and rural areas - dilemmas of development (pp. 27-41). Warszawa: Instytut rolnicztwa i gospodarki zywnosciowej.

\section{Other sources}

[44] Arthur, I. K. (2008). Innovations and Experience Economy: a tool for rural food sector competitiveness and rural development [unpublished conference paper]. Accessed from https://pdfs.semanticscholar.org/a5ea/2cab5237cc7450cdffd1e990229123fccfad.pdf?_ga= 2.262493388.1974807326.1554742801-806525954.1554742801.

[45] Council Regulation (EEC) No $2658 / 87$ of 23 July 1987 on the tariff and statistical nomenclature and on the Common Custom Tariff. 
[46] Regulation (EC) No 638/2004 of the European Parliament and of the Council of 31 March 2004 on Community statistics relating to the trading of goods between Member States and repealing Council Regulation (EEC) No 3330/91. 